\title{
PHENOMENON OF PROJECTIFICATION AND THE IMPACT ON THE NATIONAL ECONOMY - CASE OF CROATIA
}

\author{
Mladen Radujković ${ }^{1}$, Sandra Matuhina ${ }^{2}$ \& Ivan Novak Iva $^{3}$
}

UDC / UDK: 65.01(083.94)(497.5)

JEL classification / JEL klasifikacija: O22

DOI: https://doi.org/10.22598/pi-be/2021.15.2.9

Original scientific paper / Izvorni znanstveni rad

Received / Primljeno: September 21, 2021 / 21. rujna 2021.

Accepted for publishing / Prihvaćeno za tisak: November 17, 2021 / 17.

studenog 2021.

\section{Summary}

Projectification has become an important phenomenon in the field of project studies. Projectification represents an important portion of the gross national product gathering significant resources in all types of industries. There is significant number of micro-level studies investigating this phenomenon but only few have investigated the macro-level design. This paper adopted approach originally implemented in Germany, Norway and Iceland. Aim of this paper is to broaden the scale of the previous research including Croatia as one of the Eastern European post transition countries. This paper offers unique results from the first projectification research of the Croatian economy based on the analysis of 250 companies. Primary data was collected through interviews with company employees. Results reveal the level of Croatian national economy projectification being below 30\% enabling sector and cross country comparison. According to results Croatia is still within the range of the European Union countries. These results add to the existing body of knowledge regarding an ongoing research of the projectification phenomenon.

Keywords: projectification; project theory; business organization; Croatia.

\footnotetext{
${ }^{1}$ Prof. dr. sc. Mladen Radujković, Croatian Association for Project Management, President, Zagreb, Croatia, E-mail: mladen@projectexpert.hr. Alma Mater Europaea ECM, Maribor, Slovenia, E-mail: mladen.radujkovic@almamater.si

2 Dr. sc. Sandra Matuhina, Ministry of Physical Planning, Construction and State Assets, Directorate for Construction, Property Valuation and Energy Efficiency in the Building Sector, Zagreb, Croatia, E-mail: sandra.matuhina@mpgi.hr

${ }^{3}$ Doc. dr. sc. Ivan Novak, Faculty of Economics and Business Zagreb, Croatia, E-mail: inovak@efzg.hr
} 


\section{PROJECT MANAGEMENT AT THE GLANCE}

Projects have become omnipresent in the economy as well as entire society. Projects organize and shape our actions at work, professional profiles and networks as well as our private lives (Jensen et al., 2016). In contrast to usual organisation of activities projects should have a minimum duration of four weeks with more than three parties contributing which is aligned with DIN 69901 (Wald et al., 2015.). Project organising is a growing field of scholarly inquiry and management practice. In recent years, two important developments have influenced this field: (1) the study and practice of projects have extended from mainly individual projects to various macro-level designs; and (2) there is a rising interest in different kinds of scholarly inquiry (Geraldi and Söderlund, 2018). Numerous publications confirm that projects are vital for all models and levels of human networking, moreover from individual level to the entire societies, or even globally (Jensen, 2016.). According to Schoper et al. (2018) $21^{\text {st }}$ century projectification in business models has reached 30\%. Study by Wald et al. (2015) opened up a new approach to project world by announcing term "projectification", prevously unknown in standard dictionaries. By introducing projectification, the project world goes beyond established boundaries since projectification advocates project economy within the certain environment, where projects are not just tool or servant within the owner organization. The aim of this paper is to bring findings from projectification study of a small and open economy with previous transitional background represented by Croatia. Country is balancing among global market trends, local needs and resources and enlarged project activities, primarily due to positive impact of co-financing coming from the valuable EU programs and initiatives.

\section{INTRODUCTION TO THE PREVIOUS RESEARCH}

Christophe Midler coined the term projectification when he described the organizational transition of the automobile manufacturer Renault from a bureaucratic, functional organization in the 1960s to a project-driven organization in the 1990s (Midler, 1995). Projectification describes trend or decision by purpose, adopted within particular entity, to significantly use project form internal activities for beliefs that such form is necessary and appropriate in today dynamic and stochastic environment. There are alternative terms within the research studies like projectification or project orientation but all share the same idea about "project role", acknowledging different approaches. By introducing a distinction between narrow and broad conceptualisations of projectification, some scholars extend this research area from its current concern with the increased primacy of projects in contemporary organisational structures into an interest for cultural and discursive processes in a society in which notions of projects are invoked (Packendorff and Lindgren, 2014). In order to signify its importance Jensen et al. (2016) recently recognized the "projectification of everything". The 25 years' overview of projectification confirmed accelerating interest for the projectification as a research topic, so "it achieved academic rigour and richness" and the number of published papers on the 
topic is "steadily growing" (Kuura, 2020.). The increasing requirements for applied project management skills and methods as criteria for project selection in the public sector highlight the importance of broader theoretical and practical understanding of the projectification (Godenhjelm et al., 2015). The projectification studies have dispersed in many directions. One of the latest research streams of scholars is projectification of economy within particular country. Those macro studies attract wider attention. Preliminary studies of total projectification in the global economy announced contribution of projects ranging from $33 \%$ to $50 \%$ for non-developed countries (Turner et al., 2010.). Following studies that used the same approach confirmed that project activities in developed countries were $35 \%$, transition countries $50 \%$ while (Kuura, 2011.) in China and India project activities range from 40 to $43 \%$ (Turner et al., 2013). In their research interviews (based on Midler, 1995), Müller et al. (2016) used 5 dimensions to identify low, medium or high level of projectification examining for context of previously identified governance and governmentality approach. The next significant step in national projectification study came from Germany. Following inspiration about projects diffusion and evolution of working procedures at the famous car manufacturer Renault (Midler, 1995.) the German projectification study (Wald et al., 2015.) provided method for measuring the level of projectification throughout industry sectors and the national economy. The stratified sample that covers national economy included selection of 500 public and private organizations that according to NACE classification represented 6 sectors. Other 4 sectors were estimated on the basis of literature and expert interview. Following this study degree of national projectification was further calculated as the contribution in the gross domestic product. Based on the same approach comparative study of national projectification was conducted for Germany, Iceland and Norway. Study results found the level of projectification of $34,7 \%$ for Germany, 32,6\% for Norway and $27,7 \%$ for Iceland (Schoper et al., 2018.). Research of projectification becomes more popular due to International Project Management Association (IPMA), which decided to provide funding for studies in several countries aiming to cover different country-profiles (Brazil, South, Africa, Italy, China and Croatia). Results for China disclosed the highest level of national projectification reaching the barrier of 42,7\% in 2016 (Ou et al., 2018.).

Preliminary result represented by simplified average indicated that portion of project work in Croatian economy (which represents small and open countries) was about $27 \%$ in 2013 , with rising trend aiming for $30 \%$ in the next five years' time (Radujkovic and Mišić, 2019.).

The previously mentioned studies of national projectification conveyed several important findings:

- Diffusion of project work in many countries across sectors is nowadays actuality. It is present in all type of countries: large and small, developed or developing regardless of geographic position, culture and history.

- Studies register large initial increase of national projectification for initial period (first-year or second-year), while later periods portraying steady growth with few percentages per year. 
- The studies confirm that project work is accepted operational model as well as employment opportunity for many people therefore bringing emergence of a the "project class" (Kovach and Kucherova, 2009.)

- Most of the studies indicated level of national projectification around 30\% (measured in working hours). Exception was China with portion above 40\% (Ou et al., 2018.). The high portion for China may result from the speed and volume of change and innovation currently present. According to UN statistics in 2014, China was still developing, but World Bank described it as "the fastest sustained expansion by a major economy in history", where high growth has enabled China, on average, to double its GDP every eight years (Ou et al., 2018.). However, measuring by the GDP per capita, due to a large population, China is still lacking behind developed countries.

- Most of the projects were internal projects and their portion ranges from $78 \%$ to $84 \%$ (Schoper et al., 2018.) while in China this portion was 83\% (Ou et al., 2018.). Such projects are usually invisible outside performing organization or hidden for wider audiences. This also indicated diffusion of project operations across various sectors including those traditionally non-project-oriented sectors. Need for transformation, change, improvement and innovation was highly recognized and many smaller internal projects were employed. Furthermore, traditionally project-oriented sectors, with external projects, often very large and expensive, frequently delivered product or services for the specified client or market.

- Significant differences were found in projectification of public sector, where results ranged from 14,2\% for Germany to 33,3 \% for Iceland (Schoper et al., 2018.). It reflects specific historical and political development of the national economy so as their agendas for strategy at large.

- Degree of projectification varies significantly across different economic sectors. As expected, traditionally project-oriented sectors have much higher projectification level (see Table 3).

- The sector with the highest projectification in most countries was Construction reaching $80 \%$ while projectification in ICT ranged from 38\% - 60\% (see Table 2).

- Developing or non-developing countries and countries undergoing transition might have higher level of projectification (Kuura, 2011). It comes from fact that project is very convenient business model in such environment. Moreover, in many cases project is precursor for starting an ongoing business.

- National projectification is a trend in many countries initiated a long time ago (Jensen et al., 2016). However, since there was no project advocate it was not always properly accounted for. Many organizations perform projects without emphasis and often fail to use available resources gathered by the modern project management profession (competence baseline, knowledge areas, methodologies, different PM artefacts).

- There is no consensus within the research community about the future development of the national projectification. While some expect steady growth by from 0,5 to $4 \%$ per year in developed economies (Schoper et al., 2018), or even higher for fast developing economies like China 4,8\% (Ou et al., (2018)., page 57), some believe "de-projectification" is about to follow (Palm and Lindahl, (2015, Jensen et al., 
(2016)). Later expectations stems from the fact "that social enterprises are keen to use projects to push in the first developing phase later being less interested in project organisation" (Bogacz-Wojtanowska, Jałocha, 2016.). Certainly, recent Covid19 circumstance will further influence the level of global and international participation in projects.

- Interesting finding came from the Chinese study. They applied additional projectification measurement where the cost of project personnel vs. cost of total personnel was a representation of the level of projectification, especially in terms of calculating contributions of project work to individual industrial added values. Gathered projectification values were significantly lower compared to traditional approach (30,3\% instead of previous 40,7\%) (Ou et al., 2018.). It is possible that the project work assumes relatively more working hours and less financing.

- Although only few studies address financial aspects of projectification this dimension is also very important

Based on these findings it is clear that the projects are omnipresent in human organization and networking, including national economy. While national projectification is mostly observed by the portion of the project work it has also been argued that the projectification is a "central discursive theme in contemporary society", and "increasingly relevant for understanding of almost any aspect of the contemporary economy" (Packendorff and Lindgren (2014), Jensen et al., (2016)). Projects are tools for design and implementation of change as well as tools for strategy implementation. In addition, projectification does not only have an impact on the competitiveness of an individual company, but also on the competitiveness of economies and communities, either local or national (Jonasson and Ingason, 2018).

\section{METHODOLOGY AND SAMPLE}

National projectification study for Croatia was primarily inspired by the study of Schoper et al. (2018). International Project Management Association (IPMA) supported the research since Croatia is a small and open economy recently undergoing transition. The research methodology focused on the original study done in Germany (Wald et al., 2015.). Due to specifics of the Croatian economy certain methodology adaptations were necessary. The main hypotheses of the study were as follows:

H1: The total portion of the project work in the Croatian economy is within the range of other EU-countries.

H2: Distribution of projects across key sectors reflects presence of project work in every sector

H3: Top contributing sectors in the economy are above the national projectification average

H4: The level of Croatian national projectification was rising during the last five years' period and such trend is expected to continues 
H5: Projectification of the Croatian economy has characteristic of increased share of project work, but also by emerging of new paradigm in business opportunities for development, adaptation, reconstructing and changes.

According to data availability study was focused on the period of from 2013 to 2017. Sample of 250 organizations was selected (public and private) across the key sectors of the economy. For each participating company relevant data was collected including general business information and information about project work. Data revision proved projectification information was available and the level of project work for each sector was estimated. National projectification was estimated as (weighted average) sum of sector project work pondered by sector share in the economy as whole. Study resulted with preliminary information about the national projectification level of the Croatian economy and several interesting determinants about projects performances. Qualified subcontractor was appointed to gather the primary data. Previous to data collection subcontractor meeting was held with purpose of explaining and alignment in allimportant details, including terminology in project management, objectives of the study, expected results, methods and processes, timeline, etc. In parallel, subcontractor was obligated to organize preparation meeting with each respondent in each of the selected organization, prior to survey. This was organized to harmonize the process of data collection. Due to sensitivity of some data most organizations' management asked for individual information not to be available in the public. Data collection was performed by interview, combining mobile phones and/or face-to-face communication. Each respondent was contacted in two separate iterations, firstly to present the questions and relevant details, and secondly to collect the data.

Table 1. Stratified sample in Croatia - 250 companies across different sectors

\begin{tabular}{|l|c|c|c|}
\hline NACE code (Economic sector) & $\begin{array}{c}\text { Up to 250 } \\
\text { employees }\end{array}$ & $\begin{array}{c}\text { Over 250 } \\
\text { employees }\end{array}$ & Overall \\
\hline A (Agriculture, Forest, Fishing) & 8 & 2 & 10 \\
\hline $\begin{array}{l}\text { B-E (Manufacturing industry (excluding } \\
\text { construction) of which manufacturing } \\
\text { oil and gas activity) }\end{array}$ & 35 & 17 & 52 \\
\hline $\begin{array}{l}\text { G-I (Tourism and hospitality, Trade and } \\
\text { Traffic) }\end{array}$ & 45 & 30 & 75 \\
\hline J (Information \& Communication) & 8 & 2 & 10 \\
\hline K (Finance and Insurance providers) & 10 & 8 & 18 \\
\hline O-Q (Public Admin, Education, Health) & 30 & 25 & 55 \\
\hline S+F+L+M+N (Other service providers) & 20 & 10 & 30 \\
\hline Overall & 156 & 94 & 250 \\
\hline
\end{tabular}

Source: Authors calculation 
After the pilot and calibration all details about the sample size and structure were agreed. Data from the sample was collected for each sector. Data collection from some sectors was not possible due to lack of participant cooperation. Based on gathered responses from the participants' portion of project work was estimated. Projectification of the particular sectors was estimated by the mean value in the equation (1):

$$
P^{\text {sector }}=\frac{\sum_{1}^{n} P^{\text {respondent }}}{n}
$$

where " $n$ " is the number of respondent within the sector. The simple sum of projectification of each sector represents unbalanced projectification data for the economy. Therefore, contribution of each sector was estimated by the GVA in the equation (2):

$$
P^{e c o n o m y}=\sum_{j}^{m} P_{j}^{\text {sector }} \times \alpha_{j}
$$

where " $m$ " is number of sectors within the economy and $\alpha$ is specific weight of particular sector, represented by its contribution in total GVA.

\section{KEY RESULTS AND DISCUSSION}

The key results including portion of the project work, share of GVA and weighted contribution are presented in the Table 2.

Table 2. Projectification - projectification by sectors in Croatia (2017)

\begin{tabular}{|l|l|c|c|c|}
\hline $\begin{array}{l}\text { NACE } \\
\text { code }\end{array}$ & Sector & $\begin{array}{l}\text { Portion of } \\
\text { project } \\
\text { work }\end{array}$ & $\begin{array}{l}\text { Share } \\
\text { on } \\
\text { GVA* }\end{array}$ & $\begin{array}{l}\text { Weighted } \\
\text { contribution }\end{array}$ \\
\hline A & Agriculture, Forest, Fishing & $11 \%$ & $3,85 \%$ & 0,3454 \\
\hline B-E & $\begin{array}{l}\text { Manufacturing industry } \\
\text { (excluding construction) of which } \\
\text { manufacturing oil and gas activity }\end{array}$ & $38 \%$ & $\begin{array}{c}21,74 \\
\%\end{array}$ & 6,7336 \\
\hline F & Construction & $80 \%$ & $5,37 \%$ & 3,2338 \\
\hline G-I & $\begin{array}{l}\text { Retail/transport/hospitality/touris } \\
\text { m }\end{array}$ & $18 \%$ & $\begin{array}{c}22,42 \\
\%\end{array}$ & 3,2904 \\
\hline J & Information \& Communication & $52 \%$ & $4,59 \%$ & 1,9448 \\
\hline K & Finance and Insurance providers & $24 \%$ & $6,42 \%$ & 1,2552 \\
\hline L & Real estate & $2 \%$ & $\begin{array}{c}10,21 \\
\%\end{array}$ & 0,0336 \\
\hline M-N & Corporate service providers & $60 \%$ & $8,44 \%$ & 2,7852 \\
\hline O-Q & Public Admin, Education, Health & $37 \%$ & $\begin{array}{c}15,39 \\
\%\end{array}$ & 4,6398 \\
\hline S & Other service providers & $40 \%$ & $1,58 \%$ & 0,516 \\
\hline
\end{tabular}




\begin{tabular}{|l|l|c|c|c|}
$\begin{array}{l}\mathbf{S}+\mathbf{F}+\mathbf{L} \\
+\mathbf{M}-\mathbf{N}\end{array}$ & $\begin{array}{l}\text { Other service providers + real } \\
\text { estate + corporate service } \\
\text { providers }\end{array}$ & - & - & - \\
\hline & Total / Average / & $33 \%$ & $100 \%$ & $27,32 \%$ \\
\hline
\end{tabular}

*Croatian Bureau of Statistics

Source: Author's calculation

Construction as sector is fully project oriented so there was no point to measure projectification in this sector. So, construction was excluded as part of the methodology according to similar research already done. Methodology of the research focused on sectors where projectification level is not known by nature of business (Schoper et al., 2018). Schoper et al. (2018) stated that the share of project work in the remaining four economic sectors (construction, real estate, corporate service providers and agriculture, forestry and fishing) was estimated based on literature research and interviews with industry experts. In Norwegian study some parts of NACE codes were lumped together with "other service providers", "corporate service providers" and "property and accommodation". We can conclude that this NACE code takes similar impact in both mentioned (Croatia and Norway) economies, and therefore level of projectification. Unweight mean demonstrates the projectification level of $33 \%$. However, applying the share of GVA to estimate the weighted average national projectification level decreased to $27,3 \%$. The main results of the study are as follows:

- H1: The level of national projectification in Croatia based on preliminary research and the sample of 250 companies is $33 \%$. If mean value is weighted by each sector GVA contribution the projectification level decreases to $27 \%$. Acquired result is within the range gathered in previous studies in highly developed countries.

- H1: EU co-funding through different initiatives and programs has significantly increased the level of projectification. Such effects are found in other countries such as Poland and Sweden (Jalocha, 2019; Fred, 2019)

- H2: There is a differentiation of projectification level across sectors. Moreover, sectors with the highest level of projectification are Construction (74\%) and I\&C $(52 \%)$. However, those two sectors do not have the highest GVA contribution

- H3: Lowest projectification level is recorded for Agriculture, forest and fishing (11\%) and for Retail, hospitality and tourism (18\%)

- H3: Not all top GVA contributing sectors have the projectification level higher than average (i.e. Retail/Transport/Hospitality/Tourism). This may reflect that some important contributors do not maintain the speed and rhythm of projectification development

- H4: The level of Croatian national projectification was rising during the last five years and such trend is expected to continue

- H5: Study also confirmed the lack of knowledge about modern project management, project management competencies, methodologies, knowledge 
areas and other available resources developed by project management profession.

Based on the results study confirmed hypotheses $H 1, H 2$, and $H 4$, while $H 3$ and $\mathrm{H} 4$ are not significant. Results demonstrated that projectification is not phenomena only in developed countries or significant global economies. Looks like projectification of economies in many countries balance about the amount of $30 \%$. It is a global trend in business and human activities, where temporary and unique projects serve like tool for implementation of change, ideas and strategies. In that, respect some countries (i.e. China) practice higher momentum of change and innovation therefore exhibiting a higher level of projectification. Also, some countries undergoing transition, or developing countries or no-developed countries, gain from the support of international financing institutions (IFI), or by regional networking or by regional unions (i.e. EU) where financial support, loans or investments result with many more projects, and rise the projectification level. About $80 \%$ of projects in the survey were internal similar to the German study (Schoper et al., 2018.) having rather small budget and working hours, but high frequency made the difference. Rather low projectification was present in Retail/transport/ Hospitality/Tourism (18\%) which is below the national average. In parallel those sectors in Germany reached 42\% (2013.) expecting to attain $60 \%$ in the next 5 years (Schoper et al., 2018.). Similar the highest increase in project work in the last five years in Norway was present in Retail, transport, restaurant, hotel and tourism sector with total increase of $49 \%$ (2009-2014).

While making comparison among five countries (Croatia, Germany, Norway, Island and China), we concluded that there are enough similarity trends and about the leading sectors in projectification (construction and information / communication). Another interesting finding is related to the share of project work in the public sector (Croatia, 37\%, while $33.3 \%$ in Iceland, $17.8 \%$ in Germany and $14.2 \%$ in Norway). Either Croatian public sector has fast changing process or significant resources are concentrated in the public sector acting as important driver for projects. For comparison that is more detailed see Table 3 in the Appendix.

There are several emphases underlined by survey respondents:

- Despite evident increase in project, numbers there is no proper visibility within organizations. In many occasions, projects appear as tools, having low visibility in the system and high expectations about outcomes they should deliver.

- Project appointed peoples in non-project-oriented organizations are far from "project class" since they are mostly employees with "dual responsibility" simultaneously doing regular line jobs and project activities.

- While PM competences of individuals grow year-by-year, associated PM competences at the level of organizations, do not follow such trend

Most of attention focuses to a single project effect (delivery), while recently; many organizations manage project portfolios because of their strategy implementation. However, it is still beyond the focus what each project or portfolio is delivering to community, and what and how all projects within economy should contribute in development and wellbeing. Therefore, projectification studies bring new perspective and 
opportunities whereby the first step is to learn about the level of project spread in particular areas of human activities and life. Future ambition has perspective to claim for "projectification management".

\section{CONCLUSIONS, LIMITATIONS AND RECOMMENDATIONS FOR THE FURTHER RESEARCH}

The level of national projectification in Croatia was rising during the period of the last five years by approximately $1 \%$. Such trend may proceed to position Croatia within the global trends of steadily projectification growth (Kuura, 2020.). However, there is unanswered question if such growth is appropriate regarding the country needs. Consequently to projects high diffusion in every aspect of human life and particularly in business projectification is nowadays an important research stream. While result of each single project is important for many stakeholders, projects portfolios and projectification level is even more important providing opportunity for high-level strategic view on project potential, their cumulative results and benefits at large. The study of Croatian national level projectification was the first study of this kind unlocking the way for further research on the topic. Alongside with the information about the project proportion study emphasizes interesting and important information for decision makers, politicians and practitioners dealing with ongoing daily challenges looking for better, faster and more successful operational approach. Despite sampling process limitations results still provide value for research community and practice, not only for Croatia but also for the region sharing similar attributes. Further research should try to gather larger sample and more closely examine the benefits of projects. Finally, the provided information is important to reach the goal of "projectification management" therefore creating true and greatest benefits for entire society. 


\section{Appendix}

Table 3. Comparison of key projectification sectors in Croatia and other selected

\begin{tabular}{|c|c|c|c|c|}
\hline $\begin{array}{l}\text { Countr } \\
\text { y }\end{array}$ & Top GVA portion & $\begin{array}{c}\text { Projectificati } \\
\text { on }(\%)\end{array}$ & $\begin{array}{l}\text { Key sectors } \\
\text { in } \\
\text { projectificati } \\
\text { on }\end{array}$ & $\begin{array}{l}\text { Future } \\
\text { trends in } \\
\text { projectificati } \\
\text { on }\end{array}$ \\
\hline Croatia & $\begin{array}{l}\text { Retail/transport/hospitality/tou } \\
\text { rism }(18,28 \%) \text {; Manufacturing } \\
\text { industry excl. construction } \\
(38,23 \%) \text {; }\end{array}$ & 27,3 (2017.) & $\begin{array}{l}\text { Construction } \\
(80 \%) \text {, } \\
\text { Information } \\
\text { and } \\
\text { communicatio } \\
\mathrm{n}(52 \%)\end{array}$ & Growth \\
\hline $\begin{array}{l}\text { German } \\
\mathbf{y}\end{array}$ & $\begin{array}{l}\text { Manufacturing }(26,1 \%) \text {; } \\
\text { Public sector, education, } \\
\text { health }(18,1 \%)\end{array}$ & 34,7 (2013.) & $\begin{array}{l}\text { Construction } \\
(80 \%), \\
\text { Corporate } \\
\text { service } \\
\text { providers } \\
(60 \%)\end{array}$ & $\begin{array}{l}\text { Growth to } \\
42 \% \text { by } 2020 \text {. }\end{array}$ \\
\hline Norway & $\begin{array}{l}\text { Oil and gas }(23,9 \%) \text {; Public } \\
\text { sector, education, health }(22 \\
\%\end{array}$ & $32,6(2014)$. & $\begin{array}{l}\text { Oil and gas } \\
(50,7 \%) \text {, } \\
\text { Information } \\
\text { and } \\
\text { communicatio } \\
\mathrm{n}(48 \%)\end{array}$ & $\begin{array}{l}\text { Growth to } \\
34 \% \text { by } 2022 \text {. }\end{array}$ \\
\hline Island & $\begin{array}{l}\text { Retail, transport, hospitality, } \\
\text { tourism }(20,3 \%) \text {; Public } \\
\text { sector, education, health }(22,1 \\
\%)\end{array}$ & 27,7 (2014.) & $\begin{array}{l}\text { Construction } \\
(80 \%) \text {, } \\
\text { Information } \\
\text { and } \\
\text { communicatio } \\
\mathrm{n}(60 \%)\end{array}$ & $\begin{array}{l}\text { Growth to } \\
32 \% \text { by } 2022 \text {. }\end{array}$ \\
\hline China & $\begin{array}{l}\text { Manufacturing industry excl. } \\
\text { construction }(31,5 \%) \text {; Retail, } \\
\text { transport, hospitality, tourism } \\
(15,8 \%) \text {; }\end{array}$ & 42,7 (2016.) & $\begin{array}{l}\text { Construction } \\
(80 \%), \\
\text { Information } \\
\text { and } \\
\text { communicatio } \\
\mathrm{n}(60 \%)\end{array}$ & $\begin{array}{l}\text { Growth to } \\
53 \% \text { by } 2022 \text {. }\end{array}$ \\
\hline
\end{tabular}

Source: This table was extended with the research of Croatia and China according to Schoper, I. G., Wald, A., Ingason H. T. and Fridgeirsson T.V. (2018) and Ou, L., Hsiung, C., \& Wang, Y. (2018) 


\section{REFERENCES:}

1) Bogacz-Wojtanowska, E. and Jałocha, B. (2016) 'The bright side of social economy sector's projectification: a study of successful social enterprises', Project Management Research and Practice, 3, 5043. http://dx.doi.org/10.5130/pmrp.v3i0.5043

2) Fred, M. (2019) Local government projectification in practice - a multiple institutional logic perspective', Local Government Studies, pp. 1-20. http://dx.doi.org/10.1080/03003930.2019.1606799

3) Geraldi, J. and Söderlund, J. (2018) 'Project studies: What it is, where it is going', International Journal of Project Management, 36(1): 55-70. https://doi.org/10.1016/j.ijproman.2017.06.004

4) Godenhjelm, S., Lundin, R. A. and Sjöblom, S. (2015) 'Projectification in the public sector-the case of the European Union', International Journal of Managing Projects in Business, 8 (2): 324-348. https://doi.org/10.1108/IJMPB-05-2014-0049

5) International Project management Association (IPMA), Proceedings of $4^{\text {th }}$ IPMA Research Conference 'Project Management and its Impact on Societies', Rio de Janeiro, September $3^{\text {rd }}-4^{\text {th }}, 2018$., ISBN (PRINT): 978-94-92338-25-9, ISBN (PDF/A): 978-94-92338-26-6.

6) Jalocha, B. (2019) The European Union's multi-level impact on member state projectification in light of noninstitutional theory', International Journal of Managing Projects in Business, 12 (3): 578-601. http://dx.doi.org/10.1108/IJMPB09-2018-0198

7) Jensen, A., Thuesen, C. and Geraldi, J. (2016) 'The projectification of everything: projects as a human condition', Project Management Journal (47): 21-34. http://dx.doi.org/10.1177/875697281604700303

8) Jensen, A., Thuesen, C. and Geraldi, J. (2016) 'The projectification of everything: Projects as a human condition', Project Management Journal, 47 (3): 21-34. https://doi.org/10.1177/875697281604700303

9) Jonasson H. I. and Ingason H. T. (2018) 'Project Pedagogy and Projectification of Fragile Local Communities', proceedings of 6th IPMA Research Conference Project Management and its Impact on Societies', Rio de Janeiro, September 3rd 4th, pp: 167-178..

10) Kovach, I. and Kucherova, E. (2009) 'The Social Context of Project Proliferation - The Rise of a Project Class', Journal of Environmental Policy \& Planning, 11(3): 203-221. https://doi.org/10.1080/15239080903033804

11) Kuura, A. (2011) 'Policies for projectification: support, avoid or let it be? ', Estonian Discussions on Economic Policy, 19 (1): 117-136. https://doi.org/10.15157/tpep.v19i1.431

12) Kuura, A. (2020) '25 Years of Projectification Research', presented at the 9th Scientific Conference on Project Management in the Baltic States, University of 
Latvia, April 2020; republished in the PM World Journal, Vol. IX, Issue VIII, August.

13) Lundin, R.A. and Söderholm, A. (1995) 'A theory of the temporary organisation', Scandinavian Journal of Management, 11(4): 437-455. https://doi.org/10.1016/0956-5221(95)00036-U

14) Midler, C. (1995) 'Projectification of the Firm: the Renault Case', Scandinavian Journal of Management, 11(4): 363-375. https://doi.org/10.1016/09565221(95)00035-T

15) Müller, R., Zhai, L., Wang, A. and Shao, J. (2016) 'A framework for governance of projects: Governmentality, governance structure and projectification', International Journal of Project Management, 34(6): 957-969. https://doi.org/10.1016/j.ijproman.2016.05.002

16) Ou, L., Hsiung, C. and Wang, Y. (2018). 'Projectification in China: A Comparative Study of Projectification between China and European Countries, proceedings of 6th IPMA Research Conference-Project Management and its Impact on Societies', Rio de Janeiro, September 3rd-4th, 37-58.

17) Packendorff, J. and Lindgren, M. (2014) 'Projectification and its consequences: narrow and broad Conceptualisations', South African Journal of Economic and Management Sciences, 17(1): 7-21. https://doi.org/10.4102/sajems.v17i1.807

18) Packendorff, J., and Lindgren, M. (2014) 'Projectification and its consequences: Narrow and broad conceptualisations', South African Journal of Economic and Management Sciences, 17(1): 7-21. https://doi.org/10.4102/sajems.v17i1.807

19) Palm, K. and Lindahl, M. (2015) 'A project as a workplace: Observations from project managers in four R\&D and project-intensive companies', International Journal of Project Management, 33(4): 828-838. https://doi.org/10.1016/j.ijproman.2014.10.002

20) Radujković M. and Mišić S. (2019) 'Projectification of economy in a smaller country: A case from Croatia', The International Journal of Business Management and Technology, 3 (2): 44-51.

21) Schoper, I. G., Wald, A., Ingason H. T. and Fridgeirsson T.V. (2018) 'Projectification in Western economies: A comparative study of Germany, Norway and Iceland', International Journal of Project Management (36): 71-82. https://doi.org/10.1016/j.ijproman.2017.07.008

22) Turner, J.R., Anbari, F. and Bredillet, C. (2013) 'Perspectives on research in project management: the nine schools', Global Business Perspectives, 1(1): 3-28. https://doi.org/10.1007/s40196-012-0001-4

23) Turner, J.R., Huemann, M., Anbari, F.T. and Bredillet, C.N. (2010) Perspectives on projects. Abingdon, Oxon: Routledge. https://doi.org/10.4324/9780203891636

24) Wald, A., Schneider, C., Spanuth, T. and Schoper, Y. (2015) 'Towards a Measurement of "Projectification": A Study on the Share of Project-Work in the German Economy', In: Wald, A., Wagner, R., Schneider, C., Gschwendtner, M. (Eds.), Advanced Project Management: Flexibility and Innovative Capacity. vol. 4. GPM, Nürnberg, pp. 18-36. 


\title{
FENOMEN PROJEKIFIKACIJE I UTJECAJ NA NACIONALNO GOSPODARSTVO - PRIMJER HRVATSKE
}

\author{
Mladen Radujković, Sandra Matuhina \& Ivan Novak
}

\section{Sažetak}

Projektifikacija je postala važan fenomen u području istraživanja projekata. Projektifikacija predstavlja važan udio nacionalnog domaćeg proizvoda obuhvaćajući značajne resurse u svim industrijskim sektorima. Postoji značajan broj istraživanja mikro razine, ali svega nekoliko onih koje istražuju fenomen projektifikacije na makro razini. Ovaj rad koristi pristup originalno primijenjen u istraživanju projektifikacije na primjeru Njemačke, Norveške te Islanda. Cilj istraživanja je proširiti opseg prethodne studije uključivanjem Republike Hrvatske kao istočno europske post-tranzicijske zemlje. Rad nudi jedinstvene rezultate prve studije projektifikacije nacionalnog gospodarstva Republike Hrvatske koji se temelje na uzorku 250 poduzeća. Primarni podaci su prikupljeni putem intervjua zaposlenika. Rezultati ukazuju na postojeću razinu projektifikacije nacionalnog gospodarstva ispod razine od 30\% omogućujući usporedbu sektora $i$ zemalja. Prema rezultatima Republika Hrvatska se nalazi unutar raspona zemalja Europske unije. Rezultati istraživanja doprinose postojećem skupu znanja istraživačkog područja fenomena projektifikacije.

Ključne riječi: projektifikacija; teorija projekata; poslovna organizacija; Republika Hrvatska. 